\title{
Changing the Modes of National Representation: Anthologies of Lithuanian Poetry for Foreign Readers (1978-2013)
}

\section{GINTARE் BERNOTIENE்}

\begin{abstract}
This article examines how Lithuanian poetry was represented for foreign readers in 15 anthologies published from 1978 to 2013 in Lithuania and abroad. The object of investigation is not a huge corpus of authors representing the official canon but the cultural, historical, political, and aesthetic aspects of Lithuanian poetry revealed in the prefaces of the anthologies. The 35 year-long process of anthologisation reveals the changing modes of national representation: the trajectory from the unknown, closed or even censored Lithuanian literature (which was oppressed by social realism and divided in two parts - exodus and Soviet Lithuanian literature) to a united picture of national literature and later to the crumbling mosaic of its parts (representing particularities grouped by gender, generations, subjects, grouping and so on). During the Soviet period the more precise translation process of Lithuanian poetry for foreign readers became possible in $70 \mathrm{~s}$. Till the end of the $20^{\text {th }}$ century the main goal of compilers of anthologies as well as authors of prefaces was to represent national literary history beginning with the $18^{\text {th }}$ century and its origins in folk culture, and highlight the historical circumstances of delayed development of national literature. From the beginning of the $21^{\text {st }}$ century the care about national literature's representation turns into a commercial project orientated towards international text circulation. According to global conditions the political resistance clearly expressed in poetic writings which was so important for the compilers of the $20^{\text {th }}$-century anthologies has transformed into the political-economic literary battlefield (the battle for publishing, translations, resistance against the dominant literary tendencies, establishment of individuality) marking a radically different political resistance.
\end{abstract}

Keywords: Lithuanian poetry, anthology, poetry translation, national representation, political writing 


\section{Censored National Project}

The object of this paper is a set of anthologies of Lithuanian poetry for foreign readers published since the 1980 s.

One of the most enlightening and memorable ways of transmitting culture within a country, or for transferring it internationally, is by means of configurated corpora, that is, corpora whose constituent elements stand in some relation to each other in space [...] or in time [...]. The arrangement, the configuration, creates a meaning and value greater than the sum of meanings and values of the individual items taken in isolation, and translation anthologies are important manifestations of this phenomenon. (Frank 2000: 13)

However, what I researched was not so much the corpus of authors representing the official canon which would here be too difficult to discuss in detail due to its wide scope (15 anthologies). What I focused on were the cultural, historical, political, and aesthetic aspects of Lithuanian poetry mentioned in the prefaces of the anthologies.

During the Soviet period the more precise translation process of Lithuanian poetry for foreign readers became possible in the 1970s, after publishing a collection of word-by-word translations of Soviet Lithuanian poetry in Russian, which served as a promise of a future anthology (Kubilius, 1983c). Having agreed with the Union of Soviet Writers of Lithuanian SSR, in 1977 the literary critic Vytautas Kubilius compiled an anthology of Lithuanian poetry (beginning with its origins; a typewritten text), which was published in two most important languages in 1983.

A brief foreword "The Lithuanian Muse" for the anthology The Amber Lyre written by leading Soviet poet Eduardas Mieželaitis is not devoid of pathos ("Poetry is always a heroic feat”, Mieželaitis 1983: 13) and very stereotypical ("There are five thousand lakes in Lithuania and, probably, as many poets" (Mieželaitis 1983:11), Lithuania is a crossroad of the West and the East - "a modest screen between the western and the eastern parts of the continent" (Mieželaitis 1983:12); the river Nemunas as a natural boundary between Eastern and Western Europe. Mieželaitis (as well as authors of other prefaces) starts with a historical and geographical representation of the country and, typically to Soviet literary scholarship, ignores all the heritage created in the Latin language and considers the works of Kristijonas Donelaitis as marking the beginning of Lithuanian poetry. He explains poetic works drawing on the dramatic nature of historical battles that Lithuanians were involved in. The significance of the folk songs as an origin of Lithuanian poetic tradition in the anthologies is highlighted 
throughout the whole period under my investigation. ${ }^{1}$ Mieželaitis who claims that Soviet literature experiences a renaissance, immodestly celebrates it as a hymn to man (his cycle of poems "A Man” in 1962 won a Lenin's prize). It was an astonishing experience to find inside this foreign reader-orientated anthology excerpts from the Stalinist anthology of Soviet Lithuanian poetry (1940-1950, poems of Antanas Venclova, Kostas Korsakas, Salomeja Nèris). Of course, The Amber Lyre was strictly censored, and its cultural, socio-historical and literary representation was reliable only to a certain degree, while the talk about real political state's representation was quite inconceivable. Of course, no poets in exile were included.

With regard to the corpus of authors constituting the collection, the German anthology Litauische Poesie aus zwei Jahrhunderten (1983) was identical to the English one. They were both compiled by Kubilius who wrote for the German

1 In 1935-1939, 3 anthologies of Lithuanian poetry were published in German, Esperanto and Polish (Antologia poezji litewskiej. Warszawa, 1939; El litova poezio. Marijampole, Sakalas, 1938; Engert, Horst. Aus Litauischer Dichtung. Kaunas, Leipzig, 1935). During the years of Soviet occupation, further 11 anthologies for foreigners appeared besides the ones mentioned in this paper: Akrene taler / Gjendiktet til norsk av Odd Abrahamsen. Oslo: Dreyerr, 1984; Antologija Litvanske poezije XX veka / Prevod Momčilo Derkovič. Kruševac: Bagdala, 1985; Beads of Amber = Gintaro verinys / Translated by Lionginas Pažūsis, Vilnius: Vaga, 1979; Implinire / Traducere de Aurel Covaci. Bucuresti: Univers, 1988; Litauische Lyrik / Übersetzt von Lucia Baldauf. München: Wilhelm fink, 1972; Lithuanian Writers in the West. Chicago, Ill: Lithuanian Library Press and Loyda University Press, 1979; Piesni i gwiazdy. Warszawa, Panstwowy Instytut Wydawniczy, 1971; Poesi fra Litauen / Utvalg ved Finn-Henrik Aag og Zigfrydas Kalvaitis. [Melthus]: Snogfugl, 1989; Slunce v jantaru. Praha: Čekoslovensky spisovatel, 1982; Een steen helft geen hart. Oudenaarde: Uitgeverij Orion-Desclee de Brouwer, 1971; Tam gdzie malwy lśnia czerwone, Warszawa, Panstwowe Wydawnictwo Naukowe, 1973. According to: Gineitienè D., 1997, 509-511.

The anthologies of Lithuanian poetry started being compiled only in the $20^{\text {th }}$ century. Comprehensive anthologies of certain periods: Dainos pasauliui, saulei ir sau=Cantus solo, soli et sibi: Lietuvos XVII-XVIII amžiaus poezijos antologija, Vilnius, 1993 (Renesance and Baroque poetry); first anthologies of contemporary poetry: Vainikai, Kaunas, 1921, and Antrieji vainikai, Kaunas, 1936; Tarybine lietuviu poezija: 1940-1950, Vilnius, 1950 (stalinist period); Lietuviu poezija, t. 1, 2, Vilnius, 1967, Dvidešimto amžiaus lietuviu poezija, t. 1, 2, Vilnius, 1991, 1995; the most important anthologies in exile (Žemé, Los Angeles, 1951; Lietuviu poezijos antologija, Chicago, 1951, Lietuviu poezija, t. 3, Chicago, 1971); Lietuviu vaiku poezija, 1980 (poetry for children since Donelaitis). Generally speaking, among all anthologies of Lithuanian poetry those with thematic distinction prevail. 
issue an extensive analytical 25-page long preface "Der Weg der litauischen Lyrik" (which later served as a basis for other prefaces written by both Birute Ciplijauskaite and Jonas Zdanys). Kubilius' article written in 1979 is a study of the history of national literature (later in 1983 Kubilius published the entire study Lithuanian Literature and the Process of The World Literature, Kubilius 1983a) with an accomplished ambition of performing a comparative review and had only a few clearly ideology-driven evaluations, the so-called lightning conductors. The concept of a way, present in the title "Der Weg ...", alludes to the conjuncturally obligatory title of Neris' poem "The Path of the Bolshevik" as well as anticipating the much more subtly entwined image of the nation's path and a phenomenon of reflecting on the nation's destiny by means of national forms of culture. In the preface Kubilius is passionately trying to defend the full right of this phenomenon to be part of the European cultural heritage. National literature consists of everything which is created in the national language. With this perspective the historical boundaries of Lithuanian writings presented by Kubilius in the context of European processes are in line with the contemporary view (the missing thing is more attention to the literature written in Latin). Kubilius raised important questions that numerous authors of other anthologies tried to answer and prove their importance later in the prefaces of other anthologies. One question was whether the poetry of a small nation may not only be used for "domestic purposes" (Kubilius 1983b: 315), but it may also be interesting as well as unique, whereas another question dealt with the importance of social, political, and cultural references which move away from the immanent aesthetic objectives of literature.

\section{Restoring the Holiness of Lithuanian Literature}

For the context of these first anthologies for foreign readers a significant publication is the anthology Selected Poet-War Lithuanian Poetry (1978) compiled and translated by American-born bilingual Lithuanian poet and translator Jonas Zdanys. It contains a six-page preface written by the liberal-minded literary critic of the diaspora Rimvydas Šilbajoris. It is the first anthology to include poetry written in emigration (represented by 16 authors) and in Lithuania (represented by 11 authors). It is important to note that the dominant concept present in prefaces of all anthologies till the end of the century is that of the national history and literature. Šilbajoris also presents Lithuanian literature as a young phenomenon of only 200 years which is still firmly based on folk culture, songs containing fragments of national mythology and worldview, whereas linguistic data allow dating the oldest Lithuanian cultural facts not later than 
Greek and Roman civilizations. In his typical style, with a certain zest for irony, Šilbajoris overviews the greatest literary names - Kristijonas Donelaitis, Antanas Baranauskas, Maironis (whom he calls a "fervent patriotic bard, [...] an excellent poet, though somewhat prone to rhetoric and idealization" (Šilbajoris 1978: 8). He relates classical authors of the first part of the $20^{\text {th }}$ century to Russian symbolism, futurism and German expressionism (Balys Sruoga, Vincas Mykolaitis-Putinas, Jurgis Baltrušaitis; Kazys Binkis) and he also mentions representatives of the literary left Julius Janonis and Salomejja Neris as well as the Catholic wing (Bernardas Brazdžionis, Jonas Aistis). "[T]he Arcadian-Catholic poetic frame [(which was dominating in the first part of the $20^{\text {th }}$ century) $-\mathrm{GB}$ ] was insufficient for several strong talents" (Šilbajoris 1978: 19), especially for Henrikas Radauskas. In his discussion about Radauskas, Šilbajoris reveals the dominant socio-cultural standards of the $20^{\text {th }}$ century Lithuanian poetry which he did not meet such as patriotism, social protest, folklore, religion (Šilbajoris 1978: 10). Another group of writers who did not meet these characteristics were Alfonsas Nyka-Niliūnas, Algimantas Mackus, Jonas Mekas. The most prominent representatives of Soviet poetry include Eduardas Mieželaitis, Justinas Marcinkevičius, Sigitas Geda and Judita Vaičiūnaitè. Apart from Marcinkevičius towards whom Šilbajoris directs his criticism for idle talk, the poetics of other three writers is described by the author of the preface as "richly associative, suggestive and elusive in the texture of its language and in the quality of its imagery” (Šilbajoris 1978: 12). According to Šilbajoris, Geda, Tomas Venclova as well as Niliūnas and Radauskas "writing in two cultures radically opposed in their value systems, have nevertheless created a body of poetry which amounts to the beginnings of a new tradition." (Šilbajoris 1978: 12). Political evaluation of the period and its reflection in literature in this foreword emerges only when Silbajoris speaks about historical circumstances, such as political gibberish until about 1956 or hermetic ideologies (German and Russian), or in short biographical notes, for example, about Tomas Venclova, Kazys Boruta. However, it is controversial that the compilers of the anthology (written in a free country) do not dare to reveal painful facts about Kostas Kubilinskas (he was a traitor of partisans) whose works nowadays are described as "marginal" (except for his poetry for children). These facts were mentioned in a 1972 article "Puzzles of Talent" by Vytautas Kubilius which, as we know, resulted in harsh sanctions from the government. The selection of the poems and authors is rather random, however, the fact that the bibliographical section does not include period-based collections of some authors (for instance, Marcelijus Martinaitis' Kukučio balades (The Ballads of Kukutis), 1977, Marcinkevičius' Mažvydas, 1977) does not diminish the attempts to see the overall literary history which includes both works created in emigration as well as in Lithuania. 
Soon after the declaration of independence, Birute Ciplijauskaitè, a literary critic of the Catholic diaspora, compiled and translated anthologies in Spanish and French (Voces en el silencio, 1991, Vingt poètes lituaniens d'aujourd' hui, 1997, together with Nicole Laurent-Catrice). The preface written by Ciplijauskaite for the Spanish edition is an example of the traditional type of the grand historical narrative (starting with Donelaitis but also including to the Lithuanian poetry Oscar Vladislas de Lubicz-Milosz who wrote poetry in French). In her preface Ciplijauskaite draws the readers' attention to the synergy between a nation's art, its history and political circumstances. However, she fails to avoid stereotypes about "Lithuania - the land of poets" and also emphasizes the influence of national songs on the exiled poets (an attempt to idealize, diminutives, a nostalgic bond with land). Ciplijauskaitè draws convincing parallels between the Spanish civil war and the post-war periods in Lithuania. She provides a rather insightful picture of the latest literary process, i.e. poetry created in Lithuania which is difficult to translate, which is encoded and hermetical (Ciplijauskaite 1991: 16), a new literary generation (Geda, Vaičiūnaitè (ibid.)) which was liberating not only from traditional versification but also from symbols and imagery which had been established during the early occupation period. Having introduced the dichotomy of either learning to live with the regime and its ideology or internal emigration (ibid. 15), having put a greater emphasis on national motifs which increased since the Khrushchev Thaw until 1988, the beginning of publishing confession literature used as a weapon, Ciplijauskaite speaks about civil engagement (which overshadows the existential origins of literature) as a necessary element of literature and its life (ibid. 16). In addition, she sees the openness of poetry written abroad to Western philosophy and literature, unrestricted development in terms of form and the synthesis of avant-garde arts as an exclusive cultural height which was at least in part available to those engaged in creating literature in Lithuania and which served as a source of renewal for Soviet Lithuanian literature.

In the French preface N. Laurent-Catrice extends Ciplijauskaitë's idea about mature exodus work which until at least 1970 was the key source inspiring Soviet poetry. Even though copies of exodus literature circulated secretly and only among writers themselves, the interplay between two parts of Lithuanian literature as well as a strong resistance were very clear: "they insured the transfer of their state's history and its oral tradition to the wider masses" (Laurent-Catrice 1997: 9). As usual, Laurent-Catrice also presents Lithuanian $20^{\text {th }}$-century poetry as an oeuvre and sign of a traditional archaic-origin community (ibid. 10). 
Changing the Modes of National Representation

\section{In the Light of Political Writing}

In his brief preface for the Contemporary East European Poetry: An Anthology (1993, Princeton) its editor professor Emery George, born 1933 in Budapest, asserts: "All poetry is the poetry of dissent. It is born, among other instigations, of the individual artist's disagreement with his or her own reluctances. Poetry is an act of overcoming; internally, it is certainly a political act." (Emery 1993: vii) A huge corpus of Latvian and Estonian poets (Alexis Rannit, Ivar Ivask, Jaan Kaplinski, Paul-Eerik Rummo, totally 11; Astrida Ivaska, Vizma Belševica, Imants Ziedonis, Māris Čaklais, totally 9) is also included in this anthology. "Political poetry, a subgenre as rare as it is instructive" (ibid. viii) here is presented by the ample range of the diaspora and Lithuanians proper (Radauskas, Albinas Žukauskas, Eugenijus Matuzevičius, Niliūnas, Henrikas Nagys, Janina Degutytè, Vytautas P. Bložè, Marcinkevičius, Vaičiūnaitė, Venclova, Geda and Violeta Palčinskaitè), stressing that "[Q]uality and not the ideological slant was the criterion of inclusion".

\section{Entering the Economical Battlefield}

In 1997, a contemporary Lithuanian anthology of literature Lithuania: In Her Own Words was published by the publishing house "Tyto alba" at the initiative of Laima Sruoginis, its compiler. As declared in the publication itself, it was the first anthology to present "multiple layers of voices, generations, political differences, cultural diversity and literary styles" (Sruoginis 1997: 16). The sections of poetry, prose and drama written in Lithuania and abroad encompass the period from the 1950s to the 2000s. The book is supplemented by a few prefaces. Poetry is presented by a professional ten-page introduction "About Modern Lithuanian Poetry" written by Kornelijus Platelis, and a reprinted overview of Lithuanian emigration poetry written by Šilbajoris in 1972 . Having briefly overviewed the history of literature in terms of epic and lyrical origins, Platelis also stresses the significance of national songs ("The archives of the Lithuanian Academy of Sciences contain texts of about a half million folk songs", Platelis 1997: 28) for the Lithuanian poetic tradition. In the overview he analyses what lies at the core of the modernity of contemporary Lithuanian poetry and how that modernity correlates with the global literary development. Platelis uses the concept of modernity in the same sense as it was used in Soviet times, i.e. "as a concept standing in opposition to the regime's sanctioned forms of poetry" (ibid.27). So the corpus of authors in the anthology (starting with Bložè, Martinaitis, Geda and Vaičiūnaite) illustrates the main pendulum of the revival and liberation of poetry: 
The pendulum of their poetic expression does not move in a single line - from strict formal canons to a complete openness of expression, but rather from the idea of a poem as a "beautiful utterance" towards something akin to a magical structure: from a drawing-room game or ideological service towards a consideration of fundamental existential questions, from a deliberation of historicalethical community problems towards a meditation on individual existence and so on. (Ibid.28)

According to Platelis, Lithuanian poetry, which even in the post-war decade was blamed for not being ideologically sufficient (" $[\mathrm{E}]$ ven poetic delight in images of nature or the celebration of human love, friendship, or maternal emotions was labelled as an "escape" from reality and considered a political offence." (Ibid. 30)), later turned into the idyllic romanticism of Mieželaitis and other poets of his generation. Further, it developed cultivating the secret sign language, which Platelis calls just esoteric (ibid. 32), and keeping its fingers crossed. A fatal blow to social realism was struck in 1971-72 (collections by Žukauskas, Vaičiūnaitè, Geda, Jonas Juškaitis, Martinaitis). Poets who started in the seventies (Gražina Cieškaite, Romas Daugirdas, Juozas Erlickas, Antanas A. Jonynas, Donaldas Kajokas, Gintaras Patackas, Platelis) wrote poetry which was full of nihilism and offhand contempt, and, among other things, was characteristic of the humour typical of Central Europe's literatures (ibid. 34). The renaissance of Lithuanian poetry, which Platelis dates as having occurred in the 60s-70s, "[I] $\mathrm{n}$ its sense of beauty, aestheticism, poetic explorations and discoveries, and with its light decadence" (ibid.) is reminiscent of the period of Lithuanian literature in the twenties. Platelis solves the political and socio-cultural puzzle of the authoritarian period by joining together the Baroque and Latin American literature - the latter "had a substantial influence on our prose" (ibid. 35). It is worth briefly adding that the editor of the anthology Sruoginis also highlights the influence of politics on art: "It is difficult to deny the powerful role politics play in literature in general, especially in this part of the world where political movements were originally fuelled by poets and writers." (Sruoginis 1997: 18) However, differently from what is typical in Lithuanian historiography, she disregards the polite excuses made by some writers that the political regime alone (without the writers' engagement on one or the other side of the barricades) affected literature and art. Platelis concludes his introduction with a somewhat sad statement that "Lithuanian poetry no longer is dominant in our society's spiritual life and is slowly withdrawing into the same place this art form holds in the Western world." (Platelis 1997: 35)

Fourteen authors in exile and Lithuania are represented in an anthology of contemporary Lithuanian poetry Raw Amber, published by Salzburg University 
in 2002. This publishing project was dedicated to the forthcoming Frankfurt Book fair (Lithuania was its guest of honour in 2002). Publishers also tried to overcome the failure of marketing internationally their previous anthology Lithuania: In Her Own Words. The translator Laima Sruoginis cooperated with the editor Wolfgang Görtschacher, whose academic career was based on the numerous studies about small literary journals in Great Britain, so for the literature of another small country Lithuania the editor was mindful of "the Irish example“: in a romantic way he claims that in Lithuania there is no lack of poetry lovers and poets themselves enjoy great esteem. Their social role, as in Ireland, is the one of shaping of national identity (Görtschacher 2002: 12). In the preface "A Nation Sings" Sruoginis creates for the foreign reader a sense of cracking political order which she witnessed herself during the years 1988-1989 spent in Lithuania. In her words, at the dawn of the restoration of independence Lithuania was in love with itself after long years of self-disdain (Sruoginis 2002: 16), and the transformation of society was accomplished by the writers who happened to be much braver than the politicians. In an original way she explains the stereotype of Lithuania as a land of poets: not only metaphors or Aesopic language were the means invented to avoid the crushing power of censorship; the forbidden, excluded subject-matter was transposed into literature according to the metonymic principle: the motherland designated homeland, love of nature marked the very essence of strictly censored nationality. This way in the minds of the readers the recognition of realities and sentiments was established. "Thus it came about that Lithuania saw itself, even felt itself, as a nation of poets, living in and through their poetry. An unofficial statistic of the year 1989 revealed that in a country of three million, ninety thousand gave their sole occupation as 'poet'. Whether the unofficial statistic is fictitious as well is not really relevant: it points to the indubitable fact that the activity of verse-making thrived." (Sruoginis 2002: 20) It is worth noting that in Lithuania by that time the writers' community did not regard themselves as a socially privileged class (Jakonytè 2005: 165).

\section{The Last Overview of National Literary Totality}

In the $21^{\text {st }}$ century another project aspiring to shape the national literary corpus, an anthology called Breathing Free (2001), was published as a result of the personal efforts of the exiled translator Vyt. Bakaitis, who selected and translated poems. Even though it includes a few fragments by Donelaitis and Dionizas Poška, the main attention is drawn to $20^{\text {th }}$ century émigré (23) and Lithuanian poets (35) from 1920 to the latest contemporary poetry. Every author 
is thoroughly described in author-based non-compilatory commentaries. The 9-page preface "Poems of Place, Singing beyond Survival" contains the greatest emotional tension, it is written in the tight style of a New York intellectual and with trembling ellipses of masculine reticence. In the preface Bakaitis stresses the shaping influence of local (national) songs (folk songs, as he puts it - indigenous lyrics) on Lithuanian poetics. Other models of modern poetry, seen elsewhere, correlated with this characteristic feature of Lithuanian poetics. The wide geographical and historical overview targeted at the foreign reader presents the literature of the turn of the $19^{\text {th }}-20^{\text {th }}$ century as a product of delayed Enlightenment which was twice interrupted by cultural oppression (press ban and foreign censorship). Bakaitis' preface does not include the optimism of a young state's culture which is stressed by Kubilius. According to Bakaitis, combative resistance in the middle of the $20^{\text {th }}$ century was spreading in the same way, i.e. by means of anonymous folklore (Bakaitis 2001: 33). For poetry Bakaitis foresees the role of transfer of complicated experience:

[All this is touched on] in our poetry, signalling by effusive glints from its mirror a uniquely intense fusion of language and memory, and in crucial ways that will stay basic and universal without recourse to either historical or ideological justification. (Ibid. 43)

With his elitist, literature-centred stance Bakaitis leaves $20^{\text {th }}$-century Lithuanian authors in the domain of language and memory. However, reading this anthology one is left with the feeling of pride for modern, moderate, high-level Lithuanian poetry (and its translations), which, according to the compiler, retained "generative links" with world poetry (ibid. 35).

On the contrary, in his brief preface to a bilingual anthology Vierzehn litausiche Poeten (2002), the head of the Lithuanian Writers' Union and literary critic Valentinas Sventickas claims that "the key motif in poetry for a long time was the survival of the nation, and remaining in one's land. Social and national motifs gave so much power to poems that is describable only by means of aesthetic values." (Sventickas 2002: 10) "Lithuania employed underground resistance by means of art." (Ibid. 11) The anthology introduces poetry written after 1990. Sventickas notices the gradual establishment of meditative poetry, dissociation from domestic utilitarianism and the fact that poetry silently walked away from the zone of social realism (ibid.). He does not notice a clear change determined by the political reordering in the poetry that was created in an independent state. Poems of fourteen Lithuanian poets (as well as Kazys Bradūnas who moved to Lithuania and Tomas Venclova, who was residing in the USA) presents modern 
contemporary poetry (which succumbs to epics and essayist writing) whose moderate scepticism is diluted by an expressive flux of the details of a stoic experience. By the way, the influence of folk songs on the lyrical tradition of Lithuanian poetry is also mentioned in this preface.

\section{Living Through Gendered, Commercialised and "Frogish" Perspectives}

In the collection Five Lithuanian Women Poets (Judita Vaičiūnaitè, Danutè Paulauskaitè, Nijolè Miliauskaitè, Onè Baliukonè, Tautvyda Marcinkevičiūtè, 2002) compiled and translated by Zdanys, women's poetry is presented as a creative voice which for long centuries was repressed by the masculine culture and had a possibility to be heard only in the frequently mentioned form of folk songs. However, the readers of the collection can also find rather complicated and sometimes gloomy works (as Zdanys describes them) of postmodernist female writers, although perhaps only the works by Marcinkevičiūtė deserve such a description. It is symptomatic that only the preface addresses the issue of Lithuanian literary history from a gender perspective (whereas the number of female writers in the Lithuanian literary history is fairly large). The works of the represented authors that were selected for translation as a way of dissemination is based on the choice of the latest works rather than the works that have greatest literary value.

Lithuanian poetry in Italian is most systemically promoted by Pietro Umberto Dini. His continuous project In forma di parole: Mappa della poesia lituana $(2003,2006$ and 2010) presents 47 authors from Lithuania and abroad since the 1950 s to this day.

The tendency that is noticed at the end of the $20^{\text {th }}$ century is that collections of translated Lithuanian poetry have become the amphitheatre of some separate literary aspects (gender, generation, themes, groupings) rather than national totality. There are no excuses made to past centuries, dead poets are not discussed and the representation of national literature is gradually becoming a phenomenon with an evident commercial target, clearly driven by the need to present contemporary literature being created now (the collections relevant here include Six Young Lithuanian Poets, 2002, Self Portraits by Lithuanian Poets, 2004, Twelve Lithuanian Poets, 2007, Sex, Lithuanian Style: Prose and Poetry, 2011).

The translator and compiler of the Six Young Lithuanian Poets Kerry Shawn Keys in his preface makes excuses that the poets selected are not the most prominent nor represent their generation best. "The Lithuanian language, one of the most conservatively old languages in the world, is in its first stages as a written 
literary language. It is young in spirit and experimentation, and has the energy of a language that knows his importance to its people." Stressing that Keys ensures that "these poets are its conduits". (Keys 2002: 8) In the foreword for Sex, Lithuanian Style Karolis Klimka is more concerned not about literary representation but the "social and political proscriptions and prescriptions concerning sex and sexualities" (Klimka 2011: 12). Consequently, the publication balances on the thin edge of sensational kitsch.

In 2012 one of the largest French publishing houses L'Harmattan which fosters third world literatures published a bilingual collection of 17 Lithuanian women poets Cœurs ébouillantés. The compilers highlighted the reflections of Lithuanian identity and its cultural, historical experience in contemporary women witness-writing and is sketchily based on signs of its "belonging to the human civilization [civilisation humaine]" (Balčikonytė 2012: 11).

The American-Latvian scholar Inara Cedriņš, the exclusive editor of all three volumes of the Baltic Anthology, published Contemporary Lithuanian Poetry (A Baltic Anthology, Book 2) at the New Orleans University in 2013. In the preface "So Ancient and So Young: An Introduction to Lithuanian Poetry" Julie Kane stresses that the evolution of Lithuanian poetry could be understood only bearing in mind Lithuanian history and contemporary postcolonial perception which makes poets speak form the "frogish perspective", quoting the poet Laurynas Katkus. The preface does not elude historical and literary inaccuracies, though Lithuanian culture here is represented stressing not only the folk heritage but also the components of professional culture - theatre, university, etc. Kane presents a picture of cultural development in the situation of strict isolation (the press ban, the informational blockade during the Cold War, censorship and normative standards demanded by social realism). In this context the statement of the poet Eugenijus Ališanka that in the Soviet period the fiercest fight was for the free status of literature looks quite convincing. Kane illustrates the various strategies of survival in the literary field, naming writers personal histories (exile, deportation, confinement in psychiatric hospitals, the publication ban, authorities' disfavour) and states that this experience grounded the Aesopic language and prevalent metaphorisation. Kane finishes her review with antithesis of the relatively young Lithuanian poetry which was trained by various prohibitions and the postmodern state of writing anywhere in the world "with the suspicion that everything there is to say has already been said" (Kane 2013). According to the poet Giedre Kazlauskaite, "to write now is just an instinct". The spread of Lithuanian poetry may be better understood in Ališanka statement that "it was a symbol of national resistance and survival, and thus was looked upon with great piety.” (Kane 2013) 
Changing the Modes of National Representation

\title{
Conclusion
}

In the last decade there has been no lack of translations from Lithuanian. Our closest neighbours in the region or an even broader circle of European readers are familiar with Lithuanian literature. An anthology of Lithuanian poetry exists even in Persian (Handpicked Raspberries, 2008.) But I cannot forget the silent claim made by Vytautas Kubilius, when he was presenting to German readers the anthology Litauische Poesie aus zwei Jahrhunderten (Kubilius 1983c), that in 1929 the Lithuanian expressionist Kazys Boruta was knocking in vain at the doors of publishers in Berlin, trying to convince them to publish an anthology of Lithuanian lyrics.

Time has changed. The trajectory from the unknown, closed or even censored Lithuanian literature (which is oppressed by social realism and divided into two parts) to a united picture of national literature and later to the disintegrating mosaic shows that we are part of a global literary republic which is fragmented in a postmodern manner. As Bakaitis said, "[W] here poetry takes root, it defines the space it comes to occupy, whether on the page or in the mind. Poems are site-specific, as maps or mazes, at best both maps or mazes." (2001: 43) To my mind, Lithuanian literature has already passed its dark labyrinthine stage. Whereas the political-economic literary battlefield (battle for publishing, text circulation, translations, resistance against the dominant literary tendencies, establishment of individuality) analysed by Pascale Casanova marks a radically different political resistance than the one of the compilers of the $20^{\text {th }}$-century anthologies described here.

\author{
Gintarè Bernotienè \\ gintare.bernotiene@gmail.com \\ Šiuolaikinès literatūros skyrius \\ Lietuvių literatūros ir tautosakos institutas \\ Antakalnio g. 6 \\ LT-10308 Vilnius \\ LIETUVA
}

Bibliography

\section{Anthologies}

Coeurs ébouillantés $=$ Nuplikytom širdim: dix-sept poètes lituaniennes contemporaines. 2012. Coordonné par Diana Sakalauskaitè et Nicole Barrière; traductrices: Diana Sakalauskaitè et Nicole Barrière. Paris: L'Harmattan.

Contemporary East European Poetry: An Anthology. 1983. Ed. by Emery George. Ann Arbor: Ardis. 


\section{BERNOTIENE்}

Five Lithuanian Women Poets. 2002. Selected and translated from the Lithuanian by Jonas Zdanys. Vilnius: Vaga.

Gyvas atodūsis = Breathing Free: lietuviu poezijos vertimai. 2001 [sudarè ir ị anglų kalbą vertė Vyt Bakaitis]. Vilnius: Lietuvos rašytojų sąjungos leidykla.

Litauische Poesie aus zwei Jahrhunderten. 1983. Herausgegeben von V. Kubilius. [Nachdichtungen - Nachdrucke ausgenommen - liegen Interlinearübersetzungen von Dana Albertus, Irene Brewing und Elvira Bukevičiūtè zugrunde.] Berlin: Verlag Volk und Welt.

Lithuania: In Her Own Words: An Anthology of Contemporary Lithuanian Writing. 1997. Ed. by Laima Sruoginis. Vilnius: Tyto alba.

Mappa della poesia lituana del secondo Novecento. Traduzione e cura di P.U. Dini. - In forma di parole, Bologna: Associazione culturale In forma di parole; Le generazioni di mezzo: 2006, vol. 1, 226; vol. 2, 288; Poeti degli anni Settanta: 2010, vol. 3, 378.

Raw Amber: An Anthology of Contemporary Lithuanian Poetry. 2002. Ed. by Wolfgang Görtschacher \& Laima Sruoginis; translations by Laima Sruoginis. Salzburg: Poetry Salzburg at the University of Salzburg.

Selected Post-War Lithuanian Poetry. 1978. Edited and translated by Jonas Zdanys; introduction by Rimvydas Šilbajoris. New York: Manyland Books.

Self-Portraits by Lithuanian Poets. 2004. [Photography project by Artūras Valiauga, Tomas Kapočius, Paulius Mazūras and the subjects.] Vilnius: Books from Lithuania.

Sex, Lithuanian style: Prose and Poetry. 2011. Ed. by Karolis Klimka. Vilnius: Books from Lithuania.

Six young Lithuanian poets. 2002. Selected and translated by Kerry Shawn Keys. Vilnius: Vaga.

The Amber Lyre = Gintaro krašto poezija: $18^{\text {th }}-20^{\text {th }}$ Century Lithuanian poetry. 1983. [Prepared by the Union of Soviet Writers of Lithuanian SSR; compiler and author of bibliographical notes Vytautas Kubilius; foreword Eduardas Mieželaitis; editors Justinas Marcinkevičius et al.] Moscow: Raduga.

Vierzehn litauische Poeten = Keturiolika lietuviu poetų: eine Anthologie. 2002. Zusammengestellt, mit einem Vorwort und bio-bibliografischen Anmerkungen versehen von Valentinas Sventickas; aus dem Litauischen von Klaus Berthel. Vilnius: Vaga, Oberhausen: Athena.

Vingt poètes lituaniens d'aujourd'hui. 1997. Traduits par Biruté Ciplijauskaité et Nicole Laurent-Catrice. Nantes: Éd. du Petit Véhicule.

Voces en el silentio: poesía lituana contemporánea. 1991. Introducción y traducción de Biruté Ciplijauskaité. [Barcelona]: Los libros de la Frontera.

\section{Other sources:}

Balčikonytė, R. 2012. İžanga. - Coeurs ébouillantés = Nuplikytom širdim: dix-sept poètes lituaniennes contemporaines. Paris: L’Harmattan, 9-11.

Bakaitis, V. 2001. Poems of Place, Singing beyond Survival. - Gyvas atodūsis = Breathing free: lietuviu poezijos vertimai. Vilnius: Lietuvos rašytojų sąjungos leidykla, 36-44.

Casanova, P. 2004. The World Republic of Letters. Translated by M. B. DeBevoise, Cambridge, MA and London: Harvard University Press. 
Changing the Modes of National Representation

Ciplijauskaitè, B. 1991. Introducción. - Voces en el silentio: poesía lituana contemporánea / introducción y traducción de Biruté Ciplijauskaité. [Barcelona]: Los libros de la Frontera, 9-24.

Emery, G. 1983. Preface. - Contemporary East European Poetry: An Anthology. Ed. by Emery George. Ann Arbor: Ardis, vii-viii.

Frank, A. P. 2006. Anthologies of Translation. - M. Baker, ed., Routledge Encyclopedia of Translation Studies. London, New York: Routledge, 2006, 13-16.

Gineitienè, D. 1997. Bibliography of Translations of Lithuanian Literature into Foreign Languages (1927-1995). - V. Kubilius A. Samulionis, V. Vanagas, A. Zalatorius, Lithuanian Literature. Lietuvių literatūros ir tautosakos institutas: Vaga, 509-511.

Görtschacher, W. 2002. Encounters with Lithuania. - Raw Amber: An Anthology of Contemporary Lithuanian Poetry. Salzburg: Poetry Salzburg at the University of Salzburg, 9-12.

Jakonytè, L. 2005. Rašytojo socialumas: lietuvių rašytojų savivoka XX amžiaus 10-ajame dešimtmetyje. Vilnius: Lietuvių literatūros ir tautosakos institutas.

[Kane, J.] 2013. So Ancient and So Young: An Introduction to Lithuanian Poetry. Contemporary Lithuanian Poetry. A Baltic Anthology: Book Two. (Ed. Inara Cedrins). New Orleans: UNO Press, 13-27.

Klimka, K. 2011. Sex, Lithuanian Style?! - Sex, Lithuanian Style: Prose and Poetry, Vilnius: Books from Lithuania, 8-12.

Kubilius, V. 1983a. Lietuvių literatūra ir pasaulinès literatūros procesas. Vilnius: Vaga.

Kubilius, V. 1983b. Der Weg der litauischen Lyrik. - Litauische Poesie aus zwei Jahrhunderten, Berlin: Verlag Volk und Welt, 315-341.

Kubilius, V. 1983c. Антология митовской поэзии на немецком языке [Vytautas Kubilius' speech presenting the anthology in Berlin, 1983 November.] The archive of V. Kubilius (LLTI BR, F 92-3), Library fund of the Institute of Lithuanian Literature and Folklore. [Manuscript]

Laurent-Catrice, N. 1997. Préface. - Vingt poètes lituaniens d'aujourd'hui, Nantes: Éd. du Petit Véhicule, 7-10.

Mieželaitis, E. 1983. Lithuanian Muse. - The Amber Lyre = Gintaro krašto poezija: $18^{\text {th }}$ $20^{\text {th }}$ Century Lithuanian Poetry. Moscow: Raduga, 11-14.

Platelis, K. 1997. About Modern Lithuanian Poetry. - Lithuania: In Her Own Words: An Anthology of Contemporary Lithuanian Writing, Vilnius: Tyto alba, 27-35.

Sruoginis, L. 1997. Editor's Note. - Lithuania: In Her Own Words: An Anthology of Contemporary Lithuanian Writing. Vilnius: Tyto alba, 15-18.

Sruoginis, L. 2002. A Nation Sings. - Raw Amber: An Anthology of Contemporary Lithuanian Poetry, 13-22.

Sventickas, V. 2002. Pratarme. - Vierzehn litauische Poeten = Keturiolika lietuviu poetų: eine Anthologie. Vilnius: Vaga, Oberhausen: Athena, 10-13.

Šilbajoris, R. 1978. Foreword. - Selected Post-War Lithuanian Poetry. New York: Manyland Books, 5-12. 